\title{
Evaluation of Halte Bus Performance Based on User Satisfaction (Case Study of Bus Stop in Surakarta)
}

\author{
Satria Agung Wibawa \\ Universitas Veteran Bangun Nusantara \\ Sukoharjo, Indonesia \\ zatrea_wawa@yahoo.com
}

\begin{abstract}
This research intended to determine the performance of the bus stop and things that need to be improved. While, there are 3 aims of this research, namely: 1) To understand the performance of the existing Bus Stop, 2) To understand the factors that are considered important and their conditions by analyzing of Importance-Performance Analysis (IPA), and 3) To understand the factors that most influence the decision of the user to use and not use the Bus Stop. This research uses the interview method of respondents to obtain the data about community assessment of the bus stop. While in the analysis approached by using IPA method. Samples of Bus Stop data are taken at the Bus Stop along Slamet Riyadi Street of Surakarta. From the sample, traffic data is taken by using traffic count method and community assessment data using quizener method. Then, the data is analyzed by using IPA method to get an overview of the bus stop performance to see the factors that most influence the user's decision to use the bus stop.
\end{abstract}

Keywords: bus stop, performance, user satisfaction

\section{INTRODUCTION}

The Government of Surakarta uses Bus Rapid Transit (BRT) as one of the modes of transportation in Surakarta. The provision of BRT is intended to support the provision of urban public transport in accordance with the wishes of the community, namely efficient, safe, comfortable, reliable and affordable by the purchasing power of the people. The operation of BRT is expected to increase the attractiveness of public transport so that it can reduce the use of private vehicles in an effort to reduce the level of congestion, chaos and traffic accidents. For the operation of BRT, supporting facilities are needed, one of which is the bus stop

This research is used to look more closely at people's perceptions of the existence of the bus stop and what they really want about the existence of the bus stop. From this research, it is hoped that a recommendation on the bus stop can be produced as expected "to fulfill the wishes of the community", in the hope that the bus stop will be more effective and useful.

\section{METHODS}

To analyze the data about the extent of relationship between the level of user satisfaction and the performance of a service, that is used a qualitative-quantitative descriptive method namely Importance-Performance Analysis or analysis of the level of importance and performance [1] To measure the importance scale, generally it is used four-level scale of importance: very important (weight 4), important (weight 3), less important (weight 2), not important (weight 1). While to measure the performance, given four assessments, namely: very good (4), good (3), not good (2), and not good (1).

\section{DISCUSSION}

\section{A. Distribution of Respondent Answers}

For the case of the bus stop user, the dominant answer for the group of importance questions is choice (b) that represents the "important" answer. While for the group of performance questions, the dominant answer is choice (c) which represents the answer "less good".

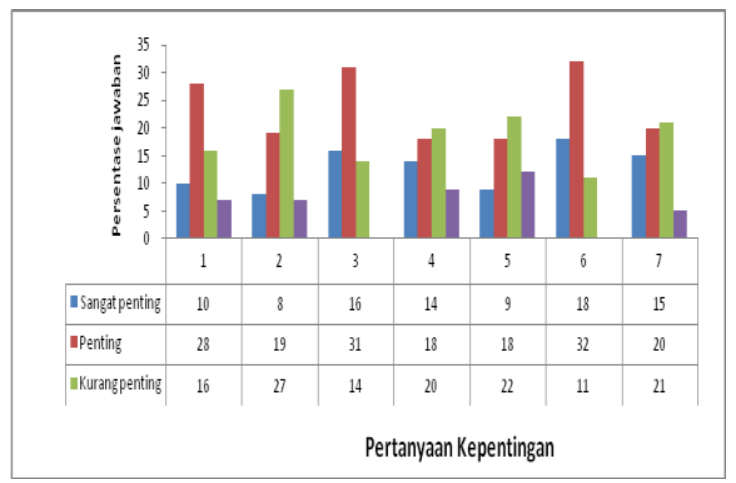

Figure 1. Distribution of interest variable answers (importance)

As for the question of performance, the dominant answer is choice (b) which also represents the answer "good".

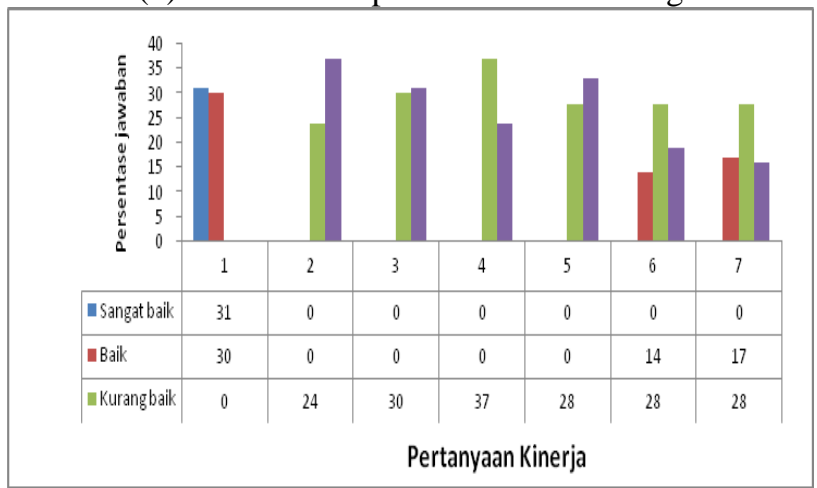

Figure 2. Distribution of answers to variable performance 


\section{B. Consistency of Respondents' Answers}

1. Consistency of the answers in a question

The consistency of answers in a question is used to see the uniformity of answers to a question by all samples of respondents taken. For this purpose diversity test is used. For convenience, test diversity using Microsoft Excel help. The results of the diversity test for all questions are shown in Table.

\begin{tabular}{|c|c|c|c|c|c|c|c|c|c|}
\hline \multirow{2}{*}{$\begin{array}{l}\mathrm{N} \\
\mathrm{o} \\
.\end{array}$} & \multirow{2}{*}{\multicolumn{2}{|c|}{ Kelompok Pertanyaan }} & \multicolumn{6}{|c|}{ Pertanyaan } & \multirow{2}{*}{$\begin{array}{l}\text { Rat } \\
\text { a- } \\
\text { Rat } \\
\text { a } \\
7\end{array}$} \\
\hline & & & 1 & 2 & 3 & 4 & 5 & 6 & \\
\hline $\begin{array}{l}1 \\
2\end{array}$ & Kepentingan & 0,89 & 0,87 & 0,49 & $\begin{array}{l}1,0 \\
0\end{array}$ & $\begin{array}{l}1,0 \\
6\end{array}$ & $\begin{array}{l}0,5 \\
0\end{array}$ & 0,90 & $\begin{array}{l}0,8 \\
2\end{array}$ \\
\hline . & Kinerja & 0,25 & 0,25 & 0,25 & $\begin{array}{l}0,2 \\
4\end{array}$ & $\begin{array}{l}0,2 \\
5\end{array}$ & $\begin{array}{l}0,5 \\
8\end{array}$ & 0,53 & $\begin{array}{l}0,3 \\
4\end{array}$ \\
\hline
\end{tabular}

Table 1. the diversity test of respondents' answers to each question

From the results of the variance test, it can be seen that the diversity of answers for importance groups above 0.5 indicates the low consistency of respondents' answers (the closer to 1 the more diverse the answers). As for the group performance (performance) the consistency of the respondent's answer is better by showing the diversity test value of less than 0.5 (the closer to 0 the more uniform the answer).[2]

a. Consistency of answers between interest groups and performance groups

Consistency of respondent's answers measures the consistency between answers to groups of importance questions and performance. Consistency is measured by using the percentage obtained from the comparison between the values in the answers of the interest group and the performance group multiplied by one hundred percent. The greater the percentage value means the better the consistency of the answers given by the respondent. [4]

The consistency of respondents' answers was $70.6 \%$ on average.

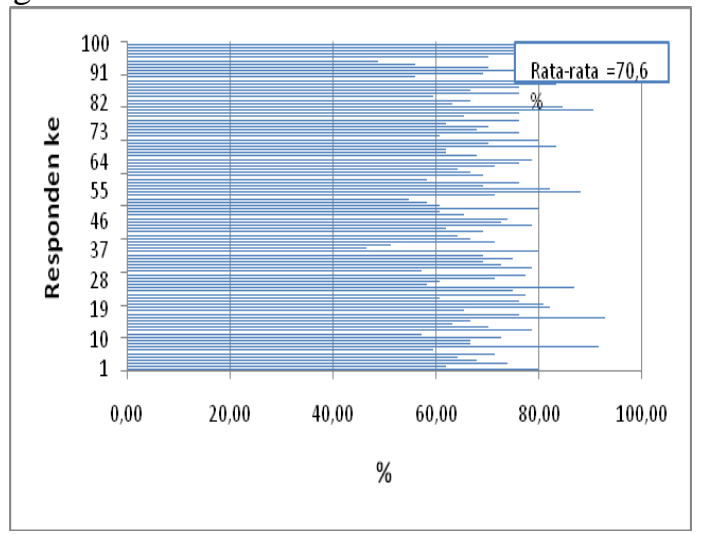

Figure 3. The level of consistency of answers to 100 respondents

All consistency values for all cases are significant, but on average still above $50 \%$. Based on the existing consistency value conditions, it can be said that for the case of the respondent's answer, it is quite consistent in answering questions in the interest group (importance) and performance (performance).

\begin{tabular}{|c|c|c|c|c|c|}
\hline \multirow[b]{2}{*}{$\begin{array}{l}\mathrm{N} \\
\mathrm{o}\end{array}$} & \multirow[b]{2}{*}{ Fakto } & \multicolumn{4}{|c|}{ Rekomendasi terhadap kinerja } \\
\hline & & $\begin{array}{l}\text { Prioritas } \\
\text { Utama } \\
\text { Diperbaiki }\end{array}$ & Pertahankan Kinerja & $\begin{array}{l}\text { Priori } \\
\text { tas } \\
\text { Rend } \\
\text { ah } \\
\text { diper } \\
\text { baiki } \\
\end{array}$ & $\begin{array}{l}\text { Kine } \\
\text { rja } \\
\text { Berle } \\
\text { bih }\end{array}$ \\
\hline 1 & $\begin{array}{l}\text { Gabung } \\
\text { an } \\
10 \\
\text { Halte } \\
\text { yang } \\
\text { disurve } \\
\text { y }\end{array}$ & & $\begin{array}{l}\text { Lokasi } \\
\text { kebersihan, } \\
\text { kenyamanan } \\
\text { keamanan } \\
\text { Jarak } \\
\text { Fisik } \\
\text { Kemudahan }\end{array}$ & & \\
\hline
\end{tabular}

The IPA analysis is intended to determine the performance of the bus stop based on the perception of the bus stop user. This analysis can show the factors are considered by [3] the user in relation to the bus stops (interests) and their current condition (performance). The IPA analysis is done using a special cartesian diagram. In this diagram each quadrant has its own definition which is defined as follows:

1). Quadrant A: located on the upper left side, means that the importance of a factor is important but its performance is low. Therefore requires immediate repairs (top priority) 2). Quadrant B: located on the upper right side, means that the importance of a factor is quite important but its performance is quite good. Therefore it requires no need for improvement (maintain achievement)

3). Quadrant C: located on the bottom side of the left, meaning that the importance of a factor is not important and its performance is low. Therefore requires repair but not immediately (low priority)

4). Awareness D: located on the bottom side of the right, means that the importance of a factor is not important but its performance is quite good. Therefore it does not need and tends to be excessive

The method of drawing cartesian science diagrams is as follows:[5]

1). The $X$ axis is drawn intersecting on the $Y$ axis at a value equal to the average performance variable ( $\left.\mathrm{X}^{\prime}\right)$

2 ). The $Y$ axis is drawn intersecting on the $X$ axis at a value equal to the average interest variable value ( $\left.\mathrm{Y}^{\prime}\right)$

3). Each factor is drawn on a diagram using the coordinates formed from the performance value pairs $(\mathrm{X})$ and interests $(\mathrm{Y})$

Scoring or assessment of each answer is done by giving a value to each answer with a nominal number. The assessment rules taken are as follows:

1) Answers (a) = very good / important, (4)

2) Answer (b) = good / important, value (3)

3) Answer (c) = poor / important (2)

4) Answer (d) = not good / important, (1)

Assessment only uses 4 (four) score classes, it is expected to see a clear enough difference between one answer to another so as to facilitate choices for respondents who are very heterogeneous. Each question is given the same weight as the assumption between factors has the same opportunity in the assessment by the respondents. 
After the assessment of each answer is given, then the average value of each question can be found which is the total value of the question in question, divided by the number of respondents who answered.

a. Respondents who use bus stops

\begin{tabular}{llll}
\hline \multirow{2}{*}{$\mathrm{N}$} & \multicolumn{2}{l}{ Scoring } \\
\cline { 3 - 4 } $\mathrm{O}$ & Variable & Kepentingan $\left(\mathrm{Y}^{\prime}\right)$ & Kinerja $\left(\mathrm{X}^{\prime}\right)$ \\
\hline 1 & Lokasi & 3,70 & 3,51 \\
2 & Jarak & 3,50 & 3,30 \\
3 & Fisik & 3,03 & 3,10 \\
4 & Kebersihan & 3,60 & 3,70 \\
5 & Kenyamanan & 1,30 & 1,46 \\
6 & Kemudahan & 3,70 & 3,60 \\
7 & Keamanan & 3,00 & 3,70 \\
& Rata-Rata & 3,12 & 3,20 \\
\hline
\end{tabular}

Table 2. The average score for each variable for interest and performance groups

In general, the average value of answers to respondents who use a bus stop is relatively high both in the group of questions related to importance and performance. It indicates that the Halte user is more optimistic in assessing the condition of the existing pedestrian bridge. Based on the scoring for each variable in the interest group and subsequent performance can be drawn in the IPA diagram in the form of a cartesian diagram.

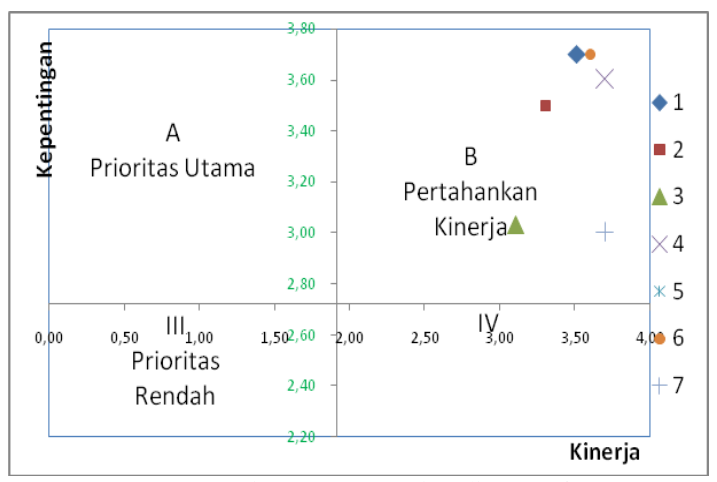

Picture 4. Cartesian diagram for IPA

\section{CONCLUSION}

Based on the results of the analysis and discussion that have been done in the previous section, some conclusions can be drawn as follows:

Community assessment of the importance of a factor related to the existence of a bus stop is very varied. But in general the assessment of factors that are considered quite important converges on 7 factors: location, distance between stops, physical condition, comfort, ease, safety, cleanliness. can be said that the existence of a bus stop is needed and all this time the performance of all shelters is running well, and the user is satisfied with the results of the IPA analysis which conveys all variables to be maintained.

\section{REFERENCES}

[1] Abubakar, I., (2002). Menuju lalu lintas dan angkutan jalan yang tertib, Dirjen Perhubungan Darat, Jakarta.

[2] Anonymous, (2009). Metode IPA, http://ariyoso.wordpress.com/2009/12/15/konsep-importanceperformance-analysis

[3] Pedoman Teknis Penyelenggaraan AngkutanPenumpang Umum di wilayah Perkotaan Dalam Trayek Tetap dan Teratur Jakarta : Departemen Perhubungan, Direktorat Jenderal Perhubungan Darat.1996

[4] Draft Pedoman Teknis Angkutan Bus Kota dengan Sistem Jalur Khusus Bus (JKB/Busway). Jakarta : Departemen Perhubungan, Direktorat Jenderal Perhubungan Darat. 2006.

[5] Direktorat Jenderal Bina Marga, 1990, Petunjuk Tertib Penggunaan Jalan Nomor 004/T/BNTK/1990, Jakarta. 